\title{
Optimal Synthesis of Substituted and Branched Pyrazines via Reaction of Alpha Hydroxy Ketones with Selected Nitrogen Sources *
}

\author{
by \\ Mehdi Ashraf-Khorassani ${ }^{1}$, William M. Coleman III, ${ }^{2}$ Michael F. Dube ${ }^{3}$, and Larry T. Taylor ${ }^{1}$ \\ ${ }^{1}$ Department of Chemistry, Virginia Tech, Blacksburg, VA 24061, USA \\ ${ }^{2}$ iii Consulting, 210 Jessamine Street, Conway, SC 29526, USA \\ ${ }^{3}$ R.J. Reynolds Tobacco Company, 950 Reynolds Blvd, Winston Salem, NC 27105, USA
}

\section{SUMMARY}

Employment of 1-hydroxy-acetone as a carbon source and $\mathrm{NH}_{4} \mathrm{OH}$ as a source of base and nitrogen, has enabled arrays of pyrazines to be synthesized. Reaction conditions such as temperature, time, carbon/nitrogen mole ratios and $\mathrm{pH}$ were optimized to maximize the quantity of pyrazines, thereby providing the synthesis of at least 19-20 structurally different pyrazines. Addition of amino acids, selected aldehydes, and hydrolyzed tobacco-derived $\mathrm{F} 1$ protein has positively impacted the array of pyrazines from both qualitative and quantitative aspects. Results further showed that by changing the carbon source from 1-hydroxy-acetone to 1-hydroxy2-butanone and/or 2-hydroxy-3-butanone, control of the type of pyrazines being synthesized could be realized in that the qualitative and quantitative distributions of the pyrazine array were shifted to higher molecular weight derivatives. A relatively large scale reaction $(1.5 \mathrm{~L})$ employing optimized parameters yielded $>2 \mathrm{~g}$ of a diverse array of pyrazines dominated by multiple dimethylpyrazine derivatives. While systematically varying reaction conditions and reagent mole ratios can predictably alter the distribution and yield of pyrazines, the two most overwhelmingly significant factors governing these two pyrazine product characteristics included the structure of the carbon source and the presence or absence of aldehydes and free amino acids. [Beitr. Tabakforsch. Int. 28 (2019) 267-277]

\section{ZUSAMMENFASSUNG}

Der Einsatz von 1-Hydroxyaceton als Kohlenstoffquelle und $\mathrm{NH}_{4} \mathrm{OH}$ als Basen- und Stickstoffquelle hat die synthetische Herstellung von Pyrazinreihen ermöglicht. Die Reaktionsbedingungen wie Temperatur, Zeit, Molverhältnisse von Kohlenstoff/Stickstoff und pH-Wert wurden mit dem Ziel optimiert, die Menge der Pyrazine zu maximieren, so dass mindestens 19-20 strukturell unterschiedliche Pyrazine synthetisiert wurden. Das Hinzufügen von Aminosäuren, ausgewählten Aldehyden und hydrolysiertem aus Tabak gewonnenem F1-Protein führte sowohl in qualitativer als auch quantitativer Hinsicht zu positiven Auswirkungen auf das Pyrazinspektrum. Aus den Ergebnissen ging weiterhin hervor, dass durch Veränderung der Kohlenstoffquelle von 1-Hydroxyaceton zu 1-Hydroxy-2-butanon und/oder 2-Hydroxy-3-butanon die Art der synthetisierten Pyrazine gesteuert werden konnte, und zwar insofern, dass sich die qualitativen und quantitativen Verteilungen des Pyrazinspektrums zu Derivaten mit höherem Molekulargewicht verschieben ließen. Eine Reaktion in relativ großem Maßstab (1,5 L) mit optimierten Parametern ergab eine Ausbeute von $>2$ g eines vielfältigen Pyrazinspektrums, das von mehreren Dimethylpyrazinderivaten dominiert war. Während die systematische Variation der Reaktionsbedingungen und Molverhältnisse der Reagenzien die Verteilung und Ausbeute von Pyrazinen vorhersagbar verändern kann, waren die beiden bei weitem signifikantesten Faktoren zur Beeinfluss- 
ung dieser beiden Eigenschaften der Pyrazinprodukte die Struktur der Kohlenstoffquelle und das Vorhandensein bzw. Fehlen von Aldehyden und freien Aminosäuren. [Beitr. Tabakforsch. Int. 28 (2019) 267-277]

\section{RESUME}

L'utilisation d'hydroxyacétone en guise de source de carbone et du $\mathrm{NH}_{4} \mathrm{OH}$ comme source d'azote et de base permit la synthèse de séries de pyrazines. Les conditions de réaction telles que la température, le temps, les rapports moléculaires carbone/azote et le $\mathrm{pH}$ furent optimisées afin de maximiser la quantité de pyrazines et ainsi de permettre la synthèse d'au-moins 19-20 pyrazines de structures différentes. L'ajout d'acides aminés, d'une sélection d'aldéhydes et d'une protéine $\mathrm{F} 1$ de tabac hydrolysée eut une incidence positive sur la série de pyrazines tant du point de vue quantitatif que qualitatif. Les résultats démontrèrent également qu'en modifiant la source de carbone en remplaçant l'hydroxyacétone par du 1-hydroxy- butanone et/ou du 2-hydroxy-3-butanone, le contrôle du type de pyrazines synthétisées pouvait être assuré grâce au glissement des distributions qualitatives et quantitatives de la série de pyrazines vers des dérivés d'un poids moléculaire plus élevé. Une réaction à relativement grande échelle $(1,5 \mathrm{~L})$ recourant aux paramètres optimisés produisit $>2 \mathrm{~g}$ d'une série variée de pyrazines où prédominaient des dérivés multiples de diméthylpyrazine. Sachant que la variation systématique des conditions de réaction et des rapports moléculaires des réactifs put, de façon prévisible, altérer la distribution et le rendement de pyrazines, les deux facteurs les plus significatifs quant aux caractéristiques de ces deux productions de pyrazines furent la structure de la source de carbone et la présence ou l'absence d'aldéhydes et d'acides aminés libres. [Beitr. Tabakforsch. Int. 28 (2019) 267-277]

\section{INTRODUCTION}

To date, the vast majority of model reactions and fortified natural products which result in pyrazine-rich formulations upon heating have used sugars such as fructose, glucose, fructose/glucose mixtures, and rhamnose as the carbon source components of the formulations. These sugars have been shown to serve as carbon sources for the formation of the pyrazine aromatic ring structure (1-11). Most often these reactions have employed ammonium hydroxide and/or free amino acids as nitrogen sources that furnish the nitrogen contained within the pyrazine structure.

Indications from the literature strongly suggest that control of the carbon source structure can dictate the structure of pyrazines when the carbon sources, other than sugars, are reacted with ammonium hydroxide $(12,13)$ to form pyrazines. Preliminary trials have indicated that a reaction between acetoin (1-hydroxyethyl-methylketone) and ammonium hydroxide produces almost exclusively tetramethylpyrazine (TMP) with small amounts of pyrazine and methylpyrazine (14). The absence of these lower molecular weight pyrazines has a positive impact on the sensory characteristics of the TMP and their absence in other pyrazine formulations could be similarly beneficial $(10,11)$. The literature suggests that acetoin is a sugar degradation intermediate that subsequently reacts with nitrogen sources to produce tetramethylpyrazine, since some tetramethylpyrazine can be detected at low levels in reactions between sugars such as fructose, glucose, and rhamnose with ammonium hydroxide (1-11). Earlier research (12, 13) supports this observation. When the carbon sources that were reacted with bases were 1-hydroxyacetone or other selected aldehydes, such as isovaleraldehyde, an array of alkyl substituted pyrazines was produced. However, the total qualitative and quantitative distribution of the pyrazine structures were not specifically delineated at the time. A re-examination of the qualitative distribution of pyrazines produced by the described reaction of 1-hydroxyacetone and ammonium hydroxide has recently been completed. Four reagent combinations were studied at a reaction temperature of $120^{\circ} \mathrm{C}$ and reaction times of 2, 8, and $12 \mathrm{~h}$ : a) 1-hydroxyacetone/isovaleraldehyde/ammonium hydroxide $(2 \mathrm{~h})$; b) 1-hydroxyacetone/ammonium hydroxide $(2 \mathrm{~h}) ; \mathrm{c})$ acetoin/ammonium hydroxide $(2 \mathrm{~h}$ and $12 \mathrm{~h}$ ); and d) 1-hydroxyacetone/acetoin/isovaleraldehyde/ ammonium hydro-xide $(8 \mathrm{~h})$. The preliminary results revealed that pyrazines having at least two alkyl substituents were synthesized and, in addition, tri- and tetra-substituted pyrazines with up to seven total carbons were prepared. Pyrazines having the isobutyl moiety, attributable to the isovaleraldehyde, attached to the ring were identified within the array. No detectable amounts of pyrazine and or methylpyrazine were found.

For this current study, a number of general hypotheses was tested. The first hypothesis is based on the theory that acetoin (2-hydroxy-3-butanone) and acetol (1-hydroxyacetone) serve as carbon sources (substitutes for sugars) and can be readily reacted with and without free amino acids in the presence of diammonium phosphate and/or $\mathrm{NH}_{4} \mathrm{OH}$ and $\mathrm{H}_{3} \mathrm{PO}_{4}$, to produce unique arrays of pyrazines, having multiple alkyl side chains and whose quantitative distribution contains little or no detectable amounts of pyrazine and methylpyrazine. The reactions were optimized using different mole ratios of carbon source to $\mathrm{NH}_{4} \mathrm{OH}(\mathrm{C}: \mathrm{N})$ ranging from 1:0.5 up to 1:2.5. Also, the effect of different reaction temperatures $\left(100-140{ }^{\circ} \mathrm{C}\right)$, reaction times (4-24 h), and $\mathrm{pH}$ levels $(8.0-11.0)$ were investigated. After optimization of the reaction, other sources of nitrogen such as amino acids or amino acids from hydrolyzed tobacco F1 protein (14) were investigated by using the optimized reaction conditions to study their effects on pyrazine distributions and yield. Optimized reaction conditions were also used for reactions of 1-hydroxy-2-butanone as a different source of carbon. Furthermore, the addition of isovaleraldehyde to one of the optimized reactions and its effects on pyrazine synthesis was also investigated.

\section{EXPERIMENTAL}

\section{Materials}

Acetoin (2-hydroxy-3-butanone), acetol (1-hydroxyacetone), 1-hydroxy-2-butanone, ammonium hydroxide (28-30\%), dichloromethane, methyl- $t$-butylether (MTBE), dichloromethane (DCM), phosphoric acid $\left(\mathrm{H}_{3} \mathrm{PO}_{4}\right)$, leucine, isoleucine, threonine, anhydrous sodium sulfate, solid phase extraction (SPE) C18 silica, and isovaleraldehyde were obtained from Sigma-Aldrich (St. Louis, MO, USA). Tobacco F1 protein 
was obtained from R.J. Reynolds Tobacco Co. (WinstonSalem, NC, USA) and hydrolyzed using optimum conditions which were developed previously (14). The enzymatic catalytic conversion of $\mathrm{F} 1$ protein to free amino acids was in the range of $50-55 \%$.

\section{Reaction protocols}

All pyrazine synthesis reactions were performed in a high pressure $40 \mathrm{~mL}$ Parr vessel, a sealed receptacle which could handle high pressure and temperature reactions. For all acetoin reactions, $0.8 \mathrm{~g}$ of acetoin was reacted with ammonium hydroxide $\left(\mathrm{NH}_{4} \mathrm{OH}, 27-30 \%\right)(1.8 \mathrm{~mL})$ and orthophosphoric acid $\left(\mathrm{H}_{3} \mathrm{PO}_{4}\right)$ when $20 \mathrm{~mL}$ of water was used. Different reaction temperatures $\left(90\right.$ and $\left.120^{\circ} \mathrm{C}\right), \mathrm{pH}$ values (8.0-12.0), time (4-18 h) and addition of amino acids $(0.4 \mathrm{~g})$ were examined. For all acetol and 1-hydroxy-2-butanone reactions, $1 \mathrm{~g}$ of each compound was mixed with $0.25,0.5$, 1.0 , and $1.25 \mathrm{~mL}$ of $\mathrm{NH}_{4} \mathrm{OH}$ and $10 \mathrm{~mL}$ of $\mathrm{H}_{2} \mathrm{O}$. Each reaction was mixed and heated at different temperatures $\left(100-140^{\circ} \mathrm{C}\right.$ ) for a period of $4-24 \mathrm{~h}$. The $\mathrm{pH}$ level for most of the reactions was approximately 11.0 (no adjustment was made). However, in reactions in which the $\mathrm{pH}$ level was adjusted to 8.0, concentrated $\mathrm{H}_{3} \mathrm{PO}_{4}$ was used to lower the $\mathrm{pH}$. Two different amino acids were tested as an additional source of nitrogen. In each reaction, $0.2 \mathrm{~g}$ of amino acid was added separately to each reaction so that it would be possible to study how it would affect the qualitative and quantitative pyrazine distributions. In another reaction, isovaleraldehyde was added and optimized reaction conditions were used to study the effect on the qualitative and quantitative pyrazine distributions. When the hydrolyzed F1 protein was used as a source of additional nitrogen, 10 or $20 \mathrm{~mL}$ of hydrolyzed F1 protein (which contained approximately 0.2 or $0.4 \mathrm{~g}$ of different amino acids) were used. In this reaction, $\mathrm{H}_{2} \mathrm{O}$ was not added since the hydrolyzed $\mathrm{F} 1$ protein was contained in 10 or $20 \mathrm{~mL}$ of $\mathrm{H}_{2} \mathrm{O}$. See Table 1 for a list of all reactions which were studied. After completion of each reaction, the mixture was extracted with $20-25 \mathrm{~mL}$ of dichloromethane (DCM). In each extraction, $250 \mu \mathrm{g}$ of deuterated 2-methylpyrazine (only the methyl group was deuterated) was used as an internal standard for all quantifications. For all reactions, the mixtures were stirred using a magnetic stirrer during the reaction process.

\section{Instrumentation}

All GC/MS analyses were performed using a 6890 GC equipped with a 5973 mass selective detector (MSD) from Agilent (Wilmington, DE, USA). Separations were obtained using an Agilent J\&W DB-WAXETR capillary column ( $30 \mathrm{~m}$ long $\times 250 \mu \mathrm{m}$ I.D. with a film thickness of $0.25 \mu \mathrm{m})$ (Wilmington, DE, USA). The following operating parameters were used for each analysis:

- Injection port temperature

$$
\begin{aligned}
& 260{ }^{\circ} \mathrm{C} \\
& 3 \mathrm{~mL} / \mathrm{min} \\
& 1 \mathrm{~min} \\
& 24 \mathrm{~mL} / \mathrm{min} \\
& 1 \mathrm{~mL} / \mathrm{min} \\
& 2 \mu \mathrm{L} \text {, split } 1: 20
\end{aligned}
$$

- Injection volume

- Column oven initial temperature
- Column oven initial time

- Column oven ramp rate

- Column oven final temperature

- Column oven final time

- MSD Transfer line temperature
$3 \mathrm{~min}$

$15^{\circ} \mathrm{C} / \mathrm{min}$

$250{ }^{\circ} \mathrm{C}$

$1 \mathrm{~min}$

$260{ }^{\circ} \mathrm{C}$

MS Wiley library was used to identify each pyrazine. For analysis, pyrazines were quantified using single ion monitoring mode. Each pyrazine was quantified against the response for a known mass of internal standard $(250 \mu \mathrm{g})$ added to the extraction solvent.

\section{RESULTS AND DISCUSSION}

\section{Reaction using acetoin (2-hydroxy-3-butanone)}

In this reaction, acetoin $(0.8 \mathrm{~g})$ was reacted with $\mathrm{NH}_{4} \mathrm{OH}$ $(1.8 \mathrm{~mL})$ and $\mathrm{H}_{3} \mathrm{PO}_{4}(0.6 \mathrm{~mL})$ at $\mathrm{pH} 8.0$ at $90{ }^{\circ} \mathrm{C}$ for $12-15$ h. More than $90 \%$ of the acetoin was converted to tetramethylpyrazine, with no pyrazine or methylpyrazine, or any other pyrazines detected in the chromatographic total ion current profile. Next, the reaction was repeated using identical conditions, but instead of heating the reaction at $90{ }^{\circ} \mathrm{C}$ for $12-15 \mathrm{~h}$, it was heated for $4 \mathrm{~h}$ at $120^{\circ} \mathrm{C}$. Results were similar to those obtained at $90{ }^{\circ} \mathrm{C}$ and $12-15 \mathrm{~h}$.

In order to determine if branched pyrazines, that is pyrazines having Strecker aldehyde-like alkyl chains, could be synthesized, an amino acid (leucine) was added to the reaction mixture composed of $0.8 \mathrm{~g}$ acetoin, $1.8 \mathrm{~mL}$ of $\mathrm{NH}_{4} \mathrm{OH}$, $0.6 \mathrm{~mL}$ of $\mathrm{H}_{3} \mathrm{PO}_{4}$, and $0.25 \mathrm{~g}$ of leucine. These reagents were mixed with $20 \mathrm{~mL}$ of $\mathrm{H}_{2} \mathrm{O}$ and $\mathrm{pH}$ was adjusted to 8.0. The Strecker degradation is a chemical reaction which converts an alpha amino acid into an aldehyde that contains the amino acid alkyl side chain. For example, should the alpha amino acid valine take part in a Strecker degradation then 2-methylpropanal would be the predicted corresponding aldehyde. The reaction mixture was heated for $18 \mathrm{~h}$ at $120^{\circ} \mathrm{C}$ and then the reaction mixture was extracted with $30 \mathrm{~mL}$ of DCM and analyzed via GC/MS. In this reaction the only pyrazine detected was tetramethylpyrazine (TMP) and unreacted acetoin. Somewhat surprisingly, pyrazines with branched alkyl substituents were not detected, indicating that the reaction between acetoin and $\mathrm{NH}_{4} \mathrm{OH}$ must be the dominant reaction pathway here and Strecker aldehyde formation does not play a significant role under these conditions.

A similar reaction was performed but instead of leucine and $\mathrm{H}_{2} \mathrm{O}, 20 \mathrm{~mL}$ of hydrolyzed $\mathrm{F} 1$ protein was used for the reaction. The reaction was performed in a Parr vessel, similar to above reaction, at $120{ }^{\circ} \mathrm{C}$ for $18 \mathrm{~h}$. After cooling the reaction mixture $30 \mathrm{~mL}$ of DCM was used to extract the pyrazines. Again, no pyrazines with branched alkyl substituents were observed, only TMP.

In order to make sure that ammonia was not consuming all the acetoin and thus preventing the amino acid(s) from reacting with acetoin, another base $(\mathrm{NaOH})$ was used instead of $\mathrm{NH}_{4} \mathrm{OH}$ to maintain a basic $\mathrm{pH}$ greater than 8.0 under the same reaction conditions. Two reactions were performed. In the first reaction, $0.8 \mathrm{~g}$ acetoin was mixed with $0.25 \mathrm{~g}$ of leucine and $20 \mathrm{~mL}$ of $0.1 \mathrm{~N} \mathrm{NaOH}(\mathrm{pH}=12.0)$, while in the second reaction the $\mathrm{pH}$ was adjusted to 8.2 using $\mathrm{H}_{3} \mathrm{PO}_{4}$. Both reactions were heated at $120^{\circ} \mathrm{C}$ for $8 \mathrm{~h}$ using the Parr 
Table 1. Reaction conditions and reagents employed in this study.

\begin{tabular}{|c|c|c|c|c|c|c|}
\hline Reaction & $\begin{array}{l}\text { Volume hydroxy ketone } \\
(\mathrm{mL})\end{array}$ & $\begin{array}{c}\mathrm{NH}_{4} \mathrm{OH}(\mathrm{mL}) \\
+ \text { any additional reagents }\end{array}$ & $\begin{array}{c}\text { Time } \\
(\mathrm{h})\end{array}$ & $\begin{array}{c}\text { Temperature } \\
\left({ }^{\circ} \mathrm{C}\right)\end{array}$ & $\begin{array}{l}\mathrm{H}_{2} \mathrm{O} \\
(\mathrm{mL})\end{array}$ & $\mathrm{pH}$ \\
\hline 1 & $0.8 \mathrm{~mL}$ Acetoin & 1.8 & $12-15$ & 90 & 20 & 8.0 \\
\hline 2 & $0.8 \mathrm{~mL}$ Acetoin & 1.8 & 4 & 120 & 20 & 8.0 \\
\hline 3 & $0.8 \mathrm{~mL}$ Acetoin & $1.8+0.25 \mathrm{~g}$ Leucine & 4 & 120 & 20 & 8.0 \\
\hline 4 & $0.8 \mathrm{~mL}$ Acetoin & $1.8+20 \mathrm{~mL}$ of Hydrolyzed F1 & 4 & 120 & 0 & 8.0 \\
\hline 5 & $0.8 \mathrm{~mL}$ Acetoin & $0.1 \mathrm{~N} \mathrm{NaOH}+0.25 \mathrm{~g}$ Leucine & 8 & 120 & 20 & 8.0 \\
\hline 6 & $0.8 \mathrm{~mL}$ Acetoin & $0.1 \mathrm{~N} \mathrm{NaOH}+0.25 \mathrm{~g}$ Leucine & 8 & 120 & 20 & 12.0 \\
\hline 7 & $1.0 \mathrm{~mL}$ Acetol & 0.5 & 12 & 120 & 10 & 11.1 \\
\hline 8 & $1.0 \mathrm{~mL}$ Acetol & 0.5 & 12 & 120 & 10 & 8.0 \\
\hline 9 & $1.0 \mathrm{~mL}$ Acetol & 0.5 & 4 & 100 & 10 & 11.1 \\
\hline 10 & $1.0 \mathrm{~mL}$ Acetol & 0.5 & 4 & 110 & 10 & 11.1 \\
\hline 11 & $1.0 \mathrm{~mL}$ Acetol & 0.5 & 4 & 120 & 10 & 11.1 \\
\hline 12 & $1.0 \mathrm{~mL}$ Acetol & 0.5 & 8 & 100 & 10 & 11.1 \\
\hline 13 & $1.0 \mathrm{~mL}$ Acetol & 0.5 & 8 & 110 & 10 & 11.1 \\
\hline 14 & $1.0 \mathrm{~mL}$ Acetol & 0.5 & 8 & 120 & 10 & 11.1 \\
\hline 15 & $1.0 \mathrm{~mL}$ Acetol & 0.5 & 12 & 100 & 10 & 11.1 \\
\hline 16 & $1.0 \mathrm{~mL}$ Acetol & 0.5 & 12 & 110 & 10 & 11.1 \\
\hline 17 & $1.0 \mathrm{~mL}$ Acetol & 0.5 & 12 & 120 & 10 & 11.1 \\
\hline 18 & $1.0 \mathrm{~mL}$ Acetol & 1.0 & 4 & 100 & 10 & 11.1 \\
\hline 19 & $1.0 \mathrm{~mL}$ Acetol & 1.0 & 4 & 110 & 10 & 11.1 \\
\hline 20 & $1.0 \mathrm{~mL}$ Acetol & 1.0 & 4 & 120 & 10 & 11.1 \\
\hline 21 & $1.0 \mathrm{~mL}$ Acetol & 1.0 & 8 & 100 & 10 & 11.1 \\
\hline 22 & $1.0 \mathrm{~mL}$ Acetol & 1.0 & 8 & 110 & 10 & 11.1 \\
\hline 23 & $1.0 \mathrm{~mL}$ Acetol & 1.0 & 8 & 120 & 10 & 11.1 \\
\hline 24 & $1.0 \mathrm{~mL}$ Acetol & 1.0 & 12 & 100 & 10 & 11.1 \\
\hline 25 & $1.0 \mathrm{~mL}$ Acetol & 1.0 & 12 & 110 & 10 & 11.1 \\
\hline 26 & $1.0 \mathrm{~mL}$ Acetol & 1.0 & 12 & 120 & 10 & 11.1 \\
\hline 27 & $1.0 \mathrm{~mL}$ Acetol & 0.25 & 4 & 100 & 10 & 11.1 \\
\hline 28 & $1.0 \mathrm{~mL}$ Acetol & 0.25 & 4 & 110 & 10 & 11.1 \\
\hline 29 & $1.0 \mathrm{~mL}$ Acetol & 0.25 & 4 & 120 & 10 & 11.1 \\
\hline 30 & $1.0 \mathrm{~mL}$ Acetol & 0.25 & 8 & 100 & 10 & 11.1 \\
\hline 31 & $1.0 \mathrm{~mL}$ Acetol & 0.25 & 8 & 110 & 10 & 11.1 \\
\hline 32 & $1.0 \mathrm{~mL}$ Acetol & 0.25 & 8 & 120 & 10 & 11.1 \\
\hline 33 & $1.0 \mathrm{~mL}$ Acetol & 0.25 & 12 & 100 & 10 & 11.1 \\
\hline 34 & $1.0 \mathrm{~mL}$ Acetol & 0.25 & 12 & 110 & 10 & 11.1 \\
\hline 35 & $1.0 \mathrm{~mL}$ Acetol & 0.25 & 12 & 120 & 10 & 11.1 \\
\hline 36 & $1.0 \mathrm{~mL}$ Acetol & 1.0 & 12 & 140 & 10 & 11.1 \\
\hline 37 & $1.0 \mathrm{~mL}$ Acetol & 1.0 & 12 & 130 & 10 & 11.1 \\
\hline 38 & $1.0 \mathrm{~mL}$ Acetol & 1.25 & 12 & 120 & 10 & 11.1 \\
\hline 39 & $1.0 \mathrm{~mL}$ Acetol & 1.0 & 24 & 120 & 10 & 11.1 \\
\hline 40 & $1.0 \mathrm{~mL}$ Acetol & 1.0 & 16 & 130 & 10 & 11.1 \\
\hline 41 & $1.0 \mathrm{~mL}$ Acetol & 1.0 & 16 & 120 & 10 & 11.1 \\
\hline 42 & $1.0 \mathrm{~mL}$ Acetol & $1.0+0.2 \mathrm{~g}$ Isoleucine & 16 & 120 & 10 & 11.1 \\
\hline 43 & $1.0 \mathrm{~mL}$ Acetol & $1.0+0.2 \mathrm{~g}$ Threonine & 16 & 120 & 10 & 11.1 \\
\hline 44 & $1.0 \mathrm{~mL}$ Acetol & $1.0+100 \mu \mathrm{L}$ Isovaleraldehyde & 16 & 120 & 10 & 11.1 \\
\hline 45 & $1.0 \mathrm{~mL}$ Acetol & $1.0+10 \mathrm{~mL}$ of hydrolyzed F1 & 16 & 120 & 0 & 11.1 \\
\hline
\end{tabular}

vessel. After cooling the reaction, the reactants were extracted with DCM and analyzed via GC/MS. No pyrazines (not even TMP) were detected.

\section{Reaction using acetol (1-hydroxyacetone)}

Initially, 1-hydroxyacetone (acetol) was reacted with $\mathrm{NH}_{4} \mathrm{OH}$ at different mole ratios, temperatures, $\mathrm{pH}$ levels, and reaction times in order to define the optimum conditions for maximum pyrazine yields. Table 1 shows a list of conditions that were used. Table 2 shows a list of all detected DCM extracted pyrazines from the reaction between 1-hydroxy- acetone with $\mathrm{NH}_{4} \mathrm{OH}$. In Tables 2-4 appears in italics peak \#23 which represents the amount of hydroxyketone left behind in the reaction mixture after the reaction had been completed. In almost all cases the amount of hydroxyketone (1-OH acetone) decreased significantly during the reaction. Figure 1 shows the total ion current chromatogram (GC/MS) for the DCM extract of this reaction and is representative of the qualitative profile of the pyrazines produced from all reactions. The 1-hydroxyacetone reactions were performed at two different $\mathrm{pH}$ levels (8.0 and 11.0) to determine which $\mathrm{pH}$ level would provide the highest yield and largest number of pyrazines. In the first reaction, $1 \mathrm{~mL}$ of 1 -hydroxyacetone 
Table 2. Synthesized pyrazines from a reaction of acetol and $\mathrm{NH}_{4} \mathrm{OH}$ using different conditions and reagents.

\begin{tabular}{|c|c|c|c|c|}
\hline Retention time (min) & Peak \# & MW & Extractionion & Pyrazine \\
\hline 5.82 & 1 & 100 & 100 & Internal standard \\
\hline 6.57 & 2 & 108 & 108 & 2,6-dimethylpyrazine \\
\hline 6.64 & 3 & 108 & 108 & 2,5-dimethylpyrazine \\
\hline 7.257 & 4 & 122 & 122 & 2-ethyl-5-methylpyrazine \\
\hline 7.323 & 5 & 122 & 122 & 2-ethyl-6-methylpyrazine \\
\hline 7.48 & 6 & 122 & 122 & 2,3,5-trimethylpyrazine \\
\hline 7.87 & 7 & 136 & 136 & ethyldimethylpyrazine isomer \\
\hline 8.032 & 8 & 136 & 136 & ethyldimethylpyrazine isomer \\
\hline 8.18 & 9 & 136 & 136 & 2,3,5,6-tetramethylpyrazine \\
\hline 8.52 & 10 & 150 & 122 & 2,3,5-trimethyl-6-ethylpyrazine \\
\hline 8.71 & 11 & 150 & 122 & 2,6-dimethyl-3-propylpyrazine \\
\hline 8.81 & 12 & 164 & 164 & 2,5-diethyl-3,6-dimethylpyrazine \\
\hline 9.57 & 13 & 178 & 122 & 2,6-dimethyl-3-(2-methylbutyl)pyrazine \\
\hline 9.76 & 14 & 178 & 122 & 2,5-dimethyl-3-(2-methylbutyl)pyrazine \\
\hline 9.96 & 15 & 178 & 122 & 2,5-dimethyl-3-(3-methylbutyl)pyrazine \\
\hline 9.94 & 16 & 148 & 148 & 2,5-dimethyl-3-propylpyrazine \\
\hline 10.07 & 17 & 148 & 148 & dimethyl-3-cis-propenylpyrazine isomer \\
\hline 10.146 & 18 & 148 & 148 & dimethyl-3-cis-propenylpyrazine isomer \\
\hline 10.338 & 19 & 148 & 148 & 2-isopropenyl-3,6-dimethylpyrazine \\
\hline 12.57 & 20 & 164 & 122 & 2-(2-methylpropyl)-3,5-dimethylpyrazine \\
\hline 12.74 & 21 & 164 & 122 & 2,6-dimethyl-3-isobutylpyrazine \\
\hline 12.94 & 22 & 178 & 136 & 2-(2-methylpropyl)-3,5,6-trimethylpyrazine \\
\hline 6.26 & 23 & 74 & 43 & 1-OH-acetone remaining after reaction \\
\hline
\end{tabular}

was reacted with $0.5 \mathrm{~mL}$ of $\mathrm{NH}_{4} \mathrm{OH}$ and $10 \mathrm{~mL}$ of $\mathrm{H}_{2} \mathrm{O}$. The $\mathrm{pH}$ level for this reaction was measured to be around 11.0. In the second reaction, the same volume of reactant was mixed, but the $\mathrm{pH}$ level was adjusted to 8.0 using concentrated $\mathrm{H}_{3} \mathrm{PO}_{4}$. Both reactions were heated at $120{ }^{\circ} \mathrm{C}$ for $12 \mathrm{~h}$ (Figure 2). As can be observed, the yield of pyrazines was higher when the $\mathrm{pH}$ level was highest, approximately 11.0 . At the lower $\mathrm{pH}$ of approximately 8.0, the quantitative contribution from lower molecular weight pyrazines increased significantly. The quantitative distribution of the pyrazi- nes is described below. The contribution from the dimethylpyrazines is labeled $\mathrm{C} 2$, representing pyrazines with a total of 2 carbons attached to the ring. The contribution from pyrazines having a total of 3 to 4 carbons attached to the ring is labeled $\mathrm{C} 3-\mathrm{C} 4$, representing pyrazines such as ethylmethylpyrazines, diethylpyrazines, tetramethylpyrazine and the like. The contribution from pyrazines having a total of 5 or more carbons attached to the ring is labeled C5 representing pyrazines such as diethylmethylpyrazines, trimethylethylpyrazines and those pyrazines having nonlinear alkyl groups

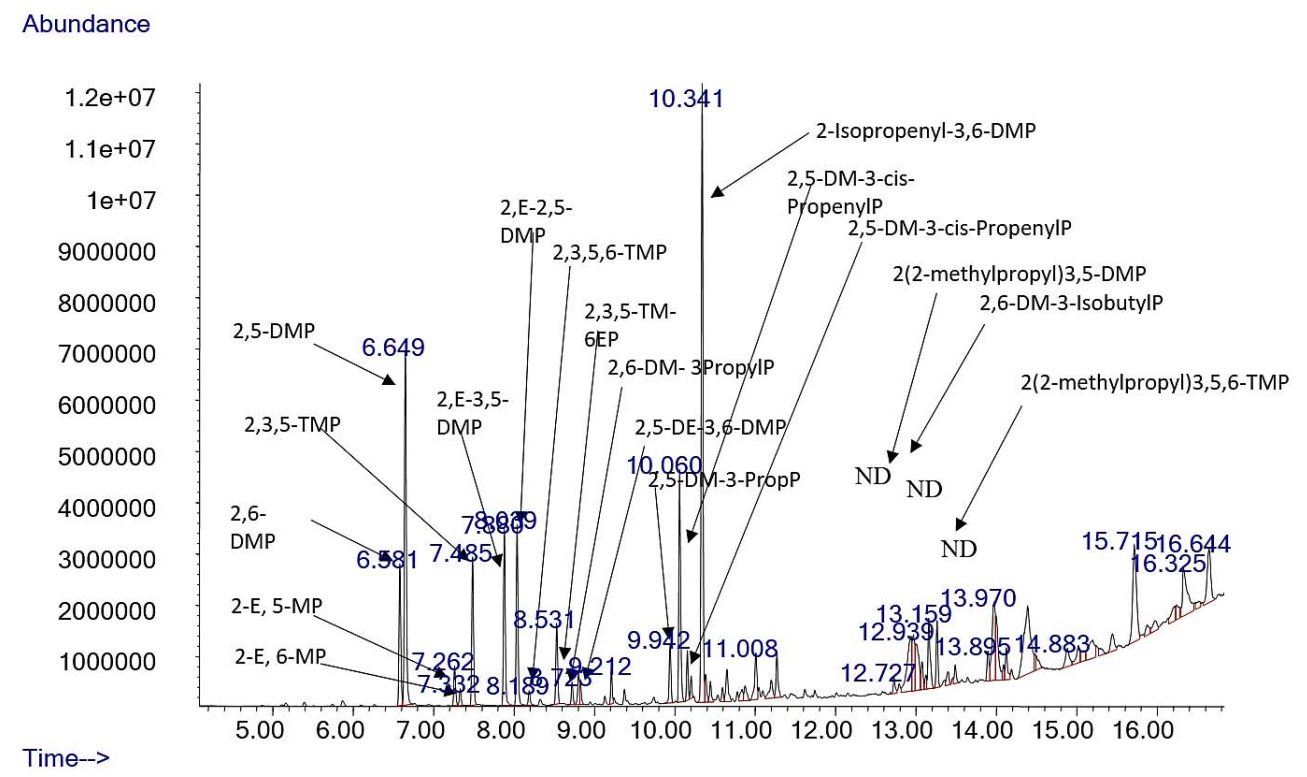

Figure 1. Total ion current (GC/MS) chromatogram of pyrazines produced as a result of the reaction between acetol and $\mathrm{NH}_{4} \mathrm{OH}$. 
attached such as isopropylmethylpyrazines and the like. No pyrazine or methylpyrazine was detected in either of these reactions mimicking the results with acetoin, see previous page. Based on these results, the $\mathrm{pH}$ level of later experiments was held at $\mathrm{pH} 11.0$ or higher.

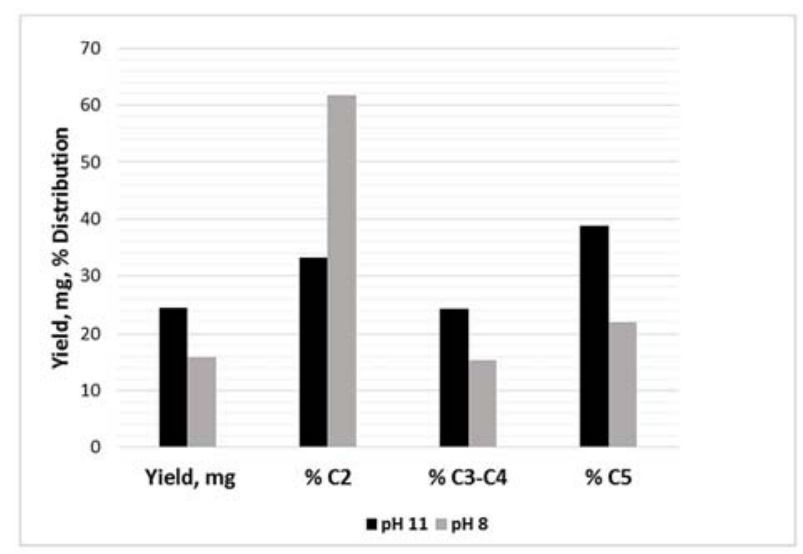

Figure 2. Effect of pH on synthesis of pyrazines using acetol and $\mathrm{NH}_{4} \mathrm{OH}$.

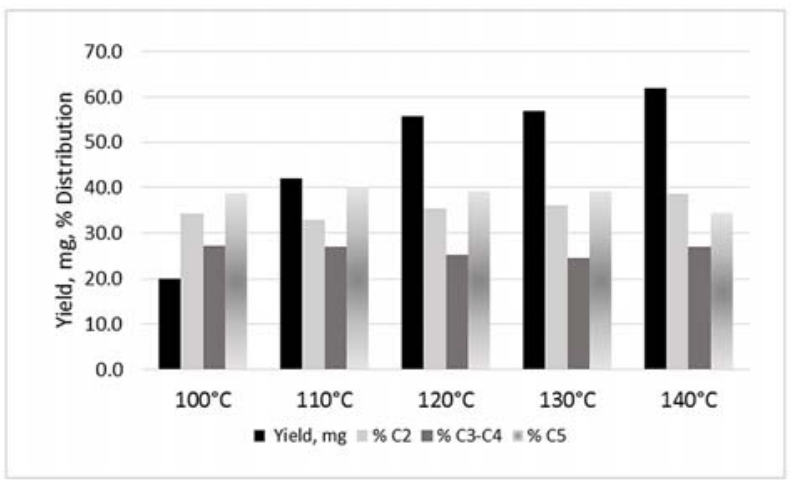

Figure 3. Effect of temperature $(100,110,120,130$, and $140{ }^{\circ} \mathrm{C}$ ) on synthesis of pyrazines using acetol and $\mathrm{NH}_{4} \mathrm{OH}$.

Figure 3 shows the effects of temperature $(100,110,120$, 130 , and $140{ }^{\circ} \mathrm{C}$ ) on the synthesis of pyrazines using 1-hydroxyacetone $(1 \mathrm{~g})$ and $\mathrm{NH}_{4} \mathrm{OH}(1 \mathrm{~g})$ with a $1: 2$ mole ratio of $\mathrm{C}: \mathrm{N}$ in $10 \mathrm{~mL}$ of $\mathrm{H}_{2} \mathrm{O}$ for $12 \mathrm{~h}$. The pyrazine yield increased as the temperature increased, continuing to show an increase in pyrazine yields at the highest temperature tested, $140{ }^{\circ} \mathrm{C}$. No notable consistent shift in pyrazine distribution was observed as a function of reaction temperature. Figure 4 shows the effect of varying reaction times (4, $8,12,16$, and $24 \mathrm{~h}$ ) on the synthesis of pyrazines using 1-hydroxyacetone $(1 \mathrm{~g})$ and $\mathrm{NH}_{4} \mathrm{OH}(1 \mathrm{~g})$ with a 1:2 mole ratio of $\mathrm{C}: \mathrm{N}$ in $10 \mathrm{~mL}$ of $\mathrm{H}_{2} \mathrm{O}$. In this part of the study, maximum yields of pyrazines were obtained when the reaction time was $16 \mathrm{~h}$ with an accompanying shift in distribution to pyrazines having higher molecular weights as the reaction time increased. Figure 5 shows the effect on pyrazine yields of an acetol: $\mathrm{NH}_{4} \mathrm{OH}$ reaction at mole ratios of $1: 0.5,1: 1,1: 2$, and $1: 2.5$ when the reaction conditions were: $10 \mathrm{~mL}$ of $\mathrm{H}_{2} \mathrm{O}, 120^{\circ} \mathrm{C}$ and $12 \mathrm{~h}$. The optimum ratio for maximum pyrazine yield was $1: 2$, which was equal to $1 \mathrm{~g}$

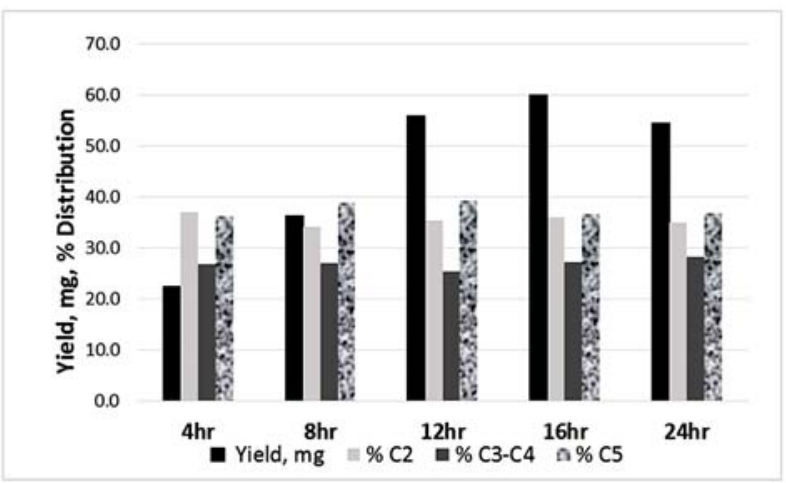

Figure 4. Effect of reaction time on synthesis of pyrazines using acetol and $\mathrm{NH}_{4} \mathrm{OH}$.

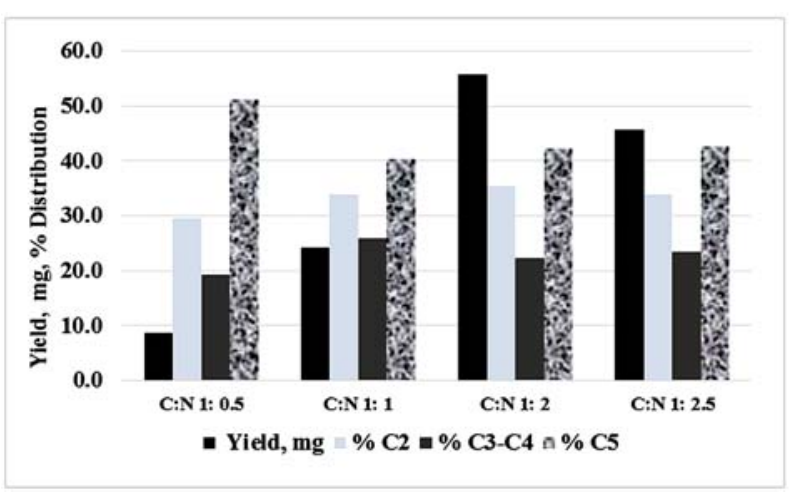

Figure 5. Effect of $\mathrm{C}: \mathrm{N}$ mole ratio on synthesis of pyrazines using acetol and $\mathrm{NH}_{4} \mathrm{OH}$.

of 1-hydroxyacetone and $1 \mathrm{~mL}$ of $\mathrm{NH}_{4} \mathrm{OH}$. When a higher volume of $\mathrm{NH}_{4} \mathrm{OH}$ was used in the reaction, the pyrazine yield of the reaction dropped by more than $10 \%$. Close examination of the structures of the pyrazines produced when acetol served as the carbon source deserves attention and reveals the absence of any detectable amounts of pyrazine and/or methylpyrazine in all of these reactions. Of significant note with this particular set of reaction conditions and reagent ratios is that when the amount of $\mathrm{NH}_{4} \mathrm{OH}$ was increased systematically, a meaningful increase in the contribution of one pyrazine, 2-isopropenyl-3,6-dimethylpyrazine, from 3.4 to $14.1 \%$ was observed.

\section{Effect of amino acids and aldehyde addition}

Table 3 shows the effects of amino acids and aldehyde additions on the reaction of 1-hydroxyacetone and $\mathrm{NH}_{4} \mathrm{OH}$ with $\mathrm{C}: \mathrm{N}$ mole ratio $1: 2$ mixed with $10 \mathrm{~mL} \mathrm{H}_{2} \mathrm{O}$ at $120^{\circ} \mathrm{C}$ for $16 \mathrm{~h}$. For this purpose, two different amino acids, as well as isovaleraldehyde were used. It was observed that when isoleucine and threonine were used as additional nitrogen sources, the contribution from $\mathrm{C} 4$ and $\mathrm{C} 5$ pyrazines increased slightly. Decreases in the contribution from the highest molecular weight pyrazines were found to have occurred. It was interesting to note that the total yields of pyrazines were similar when threonine or isoleucine was added to the reaction, both compounds having increased the total yield of pyrazine by more than $7 \%$. The addition of isovaleraldehyde to a reaction of 1-hydroxyacetone and $\mathrm{NH}_{4} \mathrm{OH}$ caused the 
Table 3. Effect on pyrazines yields and distribution of added amino acids and aldehydes to reaction of acetol and $\mathrm{NH}_{4} \mathrm{OH}$.

\begin{tabular}{l|c|c|c|c}
\hline $\begin{array}{l}\text { Reaction time }(\mathrm{h}) \\
\text { Peak \# }\end{array}$ & $\begin{array}{c}16 \mathrm{~h} \\
\text { Reaction } 41(\mathrm{mg})\end{array}$ & $\begin{array}{c}16 \mathrm{~h}+0.1 \mathrm{~g} \text { Isoleucine } \\
\text { Reaction } 42(\mathrm{mg})\end{array}$ & $\begin{array}{c}16 \mathrm{~h}+0.2 \mathrm{~g} \text { Threonine } \\
\text { Reaction 43 }(\mathrm{mg})\end{array}$ & $\begin{array}{c}16 \mathrm{~h}+100 \mu \mathrm{L} \text { Isovaleraldehyde } \\
\text { Reaction } 44(\mathrm{mg})\end{array}$ \\
\hline 1 & 0.25 & 0.25 & 0.25 & 0.25 \\
2 & $5.57(9.3)^{\mathrm{a}}$ & $7.79(12.1)$ & $7.12(10.9)$ & $6.11(7.6)^{\mathrm{a}}$ \\
3 & $16.05(26.8)$ & $20.27(31.4)$ & $18.68(28.5)$ & $14.85(18.5)$ \\
4 & $1.11(1.9)$ & $1.12(1.7)$ & $0.78(1.2)$ & $1.18(1.5)$ \\
5 & $0.47(0.8)$ & $0.48(0.8)$ & $0.26(0.4)$ & $0.46(0.6)$ \\
6 & $4.88(8.1)$ & $4.68(7.3)$ & $4.63(7.1)$ & $3.20(5.2)$ \\
7 & $3.56(5.9)$ & $3.34(5.2)$ & $7.53(11.5)$ & $2.52(3.8)$ \\
8 & $3.54(5.9)$ & $3.03(4.7)$ & $7.15(10.9)$ & $0.33(0.4)$ \\
9 & $0.42(0.7)$ & $0.29(0.5)$ & $0.32(0.5)$ & $0.74(0.9)$ \\
10 & $1.03(1.7)$ & $1.50(2.3)$ & $2.05(3.1)$ & $0.57(0.7)$ \\
11 & $0.77(1.3)$ & $1.32(2.1)$ & $1.82(2.8)$ & $0.42(0.5)$ \\
12 & $0.55(0.9)$ & $0.46(0.7)$ & $1.07(1.6)$ & $0.00(0)$ \\
13 & $0.00(0)$ & $1.02(1.6)$ & $0.00(0)$ & $14.11(17.6)$ \\
14 & $0.00(0)$ & $0.06(0.1)$ & $0.00(0)$ & $12.96(16.1)$ \\
15 & $0.00(0)$ & $0.00(0)$ & $0.00(0)$ & $0.30(0.4)$ \\
16 & $0.52(0.9)$ & $0.45(0.7)$ & $0.28(0.4)$ & $1.61(2.0)$ \\
17 & $2.12(3.5)$ & $2.12(3.3)$ & $1.38(2.1)$ & $0.33(0.4)$ \\
18 & $0.42(0.7)$ & $0.48(0.8)$ & $0.42(0.6)$ & $5.68(7.1)$ \\
19 & $8.16(13.6)$ & $5.90(9.1)$ & $3.92(6.0)$ & $4.82(6.0)$ \\
20 & $4.60(7.7)$ & $4.98(7.7)$ & $4.02(6.1)$ & $4.81(6.0)$ \\
21 & $4.75(7.9)$ & $4.21(6.5)$ & $3.19(4.9)$ & $1.25(1.6)$ \\
22 & $1.38(2.3)$ & $0.97(1.5)$ & $0.91(1.4)$ & 7.37 \\
$23^{b}$ & 0.77 & 0.81 & 7.12 & 80.28 \\
Total $\mathrm{P}^{\mathrm{c}}$ (mg) & 59.91 & 64.49 & 65.53 & \\
\hline & & & &
\end{tabular}

\footnotetext{
a The number in the brackets represents the (\%) distribution

${ }^{b}$ remaining $1-\mathrm{OH}$-acetone in $\mathrm{mg}$ after completed reaction

${ }^{\mathrm{c}} \mathrm{P}=$ Pyrazines
}

yield of 2,5-dimethyl-3-(2-methylbutyl) pyrazine and 2,5-dimethyl-3-(3-methylbutyl) pyrazine to increase from non-detected (0) to 14 and $13 \mathrm{mg}$, respective-ly. The total yield of pyrazines increased by more than $20 \%$. These results were very similar to those obtained when high fructose corn syrup (HFCS) served as the carbon source, suggesting that from a mechanistic perspective, HFCS may convert to alpha-hydroxy ketone(s) when reacted under similar conditions with similar reagents. The appearance of pyrazines with alkyl side chains having the structure of the added aldehyde was consistent with previous findings (4).

Table 4 shows the results of a similar study, but instead of using a pure amino acid, a mixture of free amino acids prepared from the hydrolysis of F1 protein was used in the reaction. Since hydrolyzed F1 protein was already in an aqueous solution, no water was added to the mixture. For this purpose, $10 \mathrm{~mL}$ of hydrolyzed $\mathrm{F} 1$ protein which contained about $0.2 \mathrm{~g}$ of amino acid and $10 \mathrm{~mL}$ of $\mathrm{H}_{2} \mathrm{O}$ was reacted with 1-hydroxyacetone and $\mathrm{NH}_{4} \mathrm{OH}$ with a $\mathrm{C}: \mathrm{N}$ mole ratio of $1: 2$ at $120{ }^{\circ} \mathrm{C}$ for $16 \mathrm{~h}$. The yield of 2,5-dimethylpyrazine increased by more than $80 \%$ and the yield of 2,5-dimethyl-3-(2-methylbutyl) pyrazine and 2,5-dimethyl3-(3-methylbutyl) pyrazine increased from 0 to more than $1 \mathrm{mg}$. Thus, most likely, the alkyl portion of specific amino acids was converted to a Strecker aldehyde which in turn reacted with the ammonium hydroxide to form an imine which subsequently was incorporated into a pyrazine structure. This observation is consistent with the literature (1-15).

Figure 6 shows additional results from a study concerning the effects of different temperatures and $\mathrm{C}: \mathrm{N}$ mole ratios $(1: 1$ and 1:2) on the synthesis of pyrazines using 1-hydroxyacetone and $\mathrm{NH}_{4} \mathrm{OH}$. In these studies, increasing the temperature from 100 to $120^{\circ} \mathrm{C}$ and manipulating the $\mathrm{C}: \mathrm{N}$ mole ratio, increased the yield of pyrazines. Increasing reaction temperatures systematically shifted the distribution of pyrazines away from $\mathrm{C} 2$ toward the higher molecular weight pyrazines represented by $\mathrm{C} 3-\mathrm{C} 4$ and $\mathrm{C} 5$ pyrazines.

\section{Reaction using 1-hydroxy-2-butanone instead of acetol}

Table 5 shows results for the reaction of 1-hydroxy-2-butanone as a different source of carbon with $\mathrm{NH}_{4} \mathrm{OH}$ at optimum conditions obtained from an initial optimization using acetol. For this purpose, $1 \mathrm{~g}$ of 1-hydroxy-2-butanone was reacted with $1 \mathrm{~mL}$ of $\mathrm{NH}_{4} \mathrm{OH}$ and $10 \mathrm{~mL}$ of $\mathrm{H}_{2} \mathrm{O}$ at $120^{\circ} \mathrm{C}$ for $16 \mathrm{~h}$. No pyrazines or methyl pyrazines were formed. All pyrazines contained ethyl or higher branched alkanes. The yield of pyrazines was, however, not as high as when acetol was used. As mentioned earlier, with acetol as the carbon source, no pyrazine or methylpyrazine was produced. With 1-hydroxy-2-butanone, no pyrazines, methylpyrazines, or standalone dimethylpyrazines were produced, confirming that the carbon source is dictating the structure of the pyrazines. The structures of acetol and 1-hydroxy-2-butanone are shown in Figure 7. It is important to note that for acetol a methyl group is bound to one side of the carbonyl and for 1-hydroxy-2-butanone an ethyl group is bound to one side of the carbonyl. These structural features of the two $\alpha, \beta$-hydroxyketones obviously dictate the structure of the 
Table 4. Effect on pyrazines yields and distribution of hydrolyzed $\mathrm{F} 1$ protein $\left(10 \mathrm{~mL}\right.$ instead of $\mathrm{H}_{2} \mathrm{O}=0.2 \mathrm{~g}$ mixture of AA's) and amino acids as nitrogen sources on reaction of acetol and $\mathrm{NH}_{4} \mathrm{OH}$.

\begin{tabular}{|c|c|c|c|c|}
\hline $\begin{array}{l}\text { Added amino acid } \\
\text { Peak \# }\end{array}$ & Reaction $4 \overline{1}$, Yield (mg) & $\begin{array}{c}0.1 \mathrm{~g} \text { Isoleucine } \\
\text { Reaction 42, Yield (mg) }\end{array}$ & $\begin{array}{c}0.2 \mathrm{~g} \text { Threonine } \\
\text { Reaction 43, Yield (mg) }\end{array}$ & $\begin{array}{c}0.2 \mathrm{~g} \text { hydrolyzed F1 } \\
\text { Reaction 45, Yield (mg) }\end{array}$ \\
\hline 1 & 0.25 & 0.25 & 0.25 & 0.25 \\
\hline 2 & $5.57(9.3)^{a}$ & $7.79(12.1)^{a}$ & $7.12(10.9)^{a}$ & $8.37(11.1)^{a}$ \\
\hline 3 & $16.05(26.8)$ & $20.27(31.4)$ & $18.68(28.5)$ & $31.01(41.3)$ \\
\hline 4 & $1.11(1.9)$ & $1.12(1.7)$ & $0.78(1.2)$ & $0.82(1.1)$ \\
\hline 5 & $0.47(0.8)$ & $0.48(0.8)$ & $0.26(0.4)$ & $0.34(0.4)$ \\
\hline 6 & $4.88(8.1)$ & $4.68(7.3)$ & $4.63(7.1)$ & $5.61(7.5)$ \\
\hline 7 & $3.56(5.9)$ & $3.34(5.2)$ & $7.53(11.5)$ & $4.18(5.6)$ \\
\hline 8 & 3.54 (5.9) & $3.03(4.7)$ & $7.15(10.9)$ & $3.50(4.7)$ \\
\hline 9 & $0.42(0.7)$ & $0.29(0.5)$ & $0.32(0.5)$ & $0.34(0.5)$ \\
\hline 10 & $1.03(1.7)$ & $1.50(2.3)$ & $2.05(3.1)$ & $2.31(3.1)$ \\
\hline 11 & $0.77(1.3)$ & $1.32(2.1)$ & $1.82(2.8)$ & $2.10(2.8)$ \\
\hline 12 & $0.55(0.9)$ & $0.46(0.7)$ & $1.07(1.6)$ & $0.55(0.7)$ \\
\hline 13 & $0.00(0)$ & $1.02(1.6)$ & $0.00(0)$ & $0.13(0.2)$ \\
\hline 14 & $0.00(0)$ & $0.06(0.1)$ & $0.00(0)$ & $1.09(1.5)$ \\
\hline 15 & $0.00(0)$ & $0.00(0)$ & $0.00(0)$ & $1.01(1.3)$ \\
\hline 16 & $0.52(0.9)$ & $0.45(0.7)$ & $0.28(0.4)$ & $0.35(0.5)$ \\
\hline 17 & $2.12(3.5)$ & $2.12(3.3)$ & $1.38(2.1)$ & $1.53(2.0)$ \\
\hline 18 & $0.42(0.7)$ & $0.48(0.8)$ & $0.42(0.6)$ & $0.40(0.5)$ \\
\hline 19 & $8.16(13.6)$ & $5.90(9.1)$ & $3.92(6.0)$ & $4.40(5.9)$ \\
\hline 20 & $4.60(7.7)$ & $4.98(7.7)$ & $4.02(6.1)$ & $3.96(5.3)$ \\
\hline 21 & $4.75(7.9)$ & $4.21(6.5)$ & $3.19(4.9)$ & $2.32(3.1)$ \\
\hline 22 & $1.38(2.3)$ & $0.97(1.5)$ & $0.91(1.4)$ & $0.85(1.1)$ \\
\hline $23^{b}$ & 0.77 & 0.81 & 7.12 & 0.67 \\
\hline Total $\mathrm{P}^{\mathrm{c}}(\mathrm{mg})$ & 59.91 & 64.49 & 65.53 & 75.15 \\
\hline
\end{tabular}

${ }^{a}$ The number in the brackets represents the (\%) distribution

${ }^{b}$ remaining $1-\mathrm{OH}$-acetone in $\mathrm{mg}$ after completed reaction

${ }^{\mathrm{c}} \mathrm{P}=$ Pyrazines

Table 5. Mass and distribution of synthesized pyrazines using 1-hydroxy-2-butanone and $\mathrm{NH}_{4} \mathrm{OH}$.

\begin{tabular}{l|c|c|l|c}
\hline Retention time $(\mathrm{min})$ & MW & Ion & Analyte & Reaction 46, Yield (mg) \\
\hline 8.01 & 136 & 136 & 2,5-diethylpyrazine & $7.28(24.7)^{\mathrm{a}}$ \\
8.35 & 150 & 150 & 2-ethyl-3,5,6-trimethylpyrazine & $1.75(5.9)$ \\
8.49 & 150 & 150 & dimethyl-2-N-propylpyrazine isomer & $0.25(0.8)$ \\
8.56 & 150 & 150 & 2,5-diethyl-3-methylpyrazine & $1.91(6.5)$ \\
8.70 & 164 & 164 & 2,3-diethyl-5,6-dimethylpyrazine & $0.38(1.3)$ \\
10.76 & 190 & 190 & trans-3-methyl-2-N-propyl-6(1-butenyl)pyrazine & $0.29(1.0)$ \\
14.07 & 136 & 136 & 2,6-dimethyl-3-ethylpyrazine isomer & $2.85(9.7)$ \\
& & & Total mass of pyrazines (mg) & 29.4
\end{tabular}

${ }^{a}$ The number in the brackets represents the (\%) distribution

resulting pyrazines, yielding only pyrazines which have multiple methyl and ethyl alkyl substituents. Studies with high fructose corn syrup instead of hydroxyketones as carbon sources have revealed a much larger array of pyrazines produced under similar reaction conditions including the less than desirable pyrazine and methylpyrazine which together have accounted for more than $50 \%$ of the pyrazine yield.

\section{Large-scale reaction of 1-hydroxyacetone and $\mathrm{NH}_{4} \mathrm{OH}$}

To test the capability for this reaction to be scaled higher, a Parr reactor with greater reaction volume was employed.
Thus, $100 \mathrm{~g}$ of 1-hydroxyacetone was reacted with $100 \mathrm{~mL}$ of $\mathrm{NH}_{4} \mathrm{OH}$ and $1000 \mathrm{~mL}$ of $\mathrm{H}_{2} \mathrm{O}$ at $120^{\circ} \mathrm{C}$ for $16 \mathrm{~h}$ in a 1.5-L Parr high-pressure vessel. After the reaction was complete, the mixture was cooled and transferred into a glass bottle. Of note here was that the bottom of the vessel contained a noticeable amount of a "tar"-like material which was soluble in $\mathrm{MeOH}$. The addition of $\mathrm{H}_{2} \mathrm{O}$ to the top of this solid material caused it to become hard. This "tar"-like material was well segregated from the aqueous solution. In addition, reagent concentration studies in a related effort have shown that overall reagent concentrations can play a significant role in the presence or absence of the "tar"-like material. For all optimization studies, vide supra, the amount 


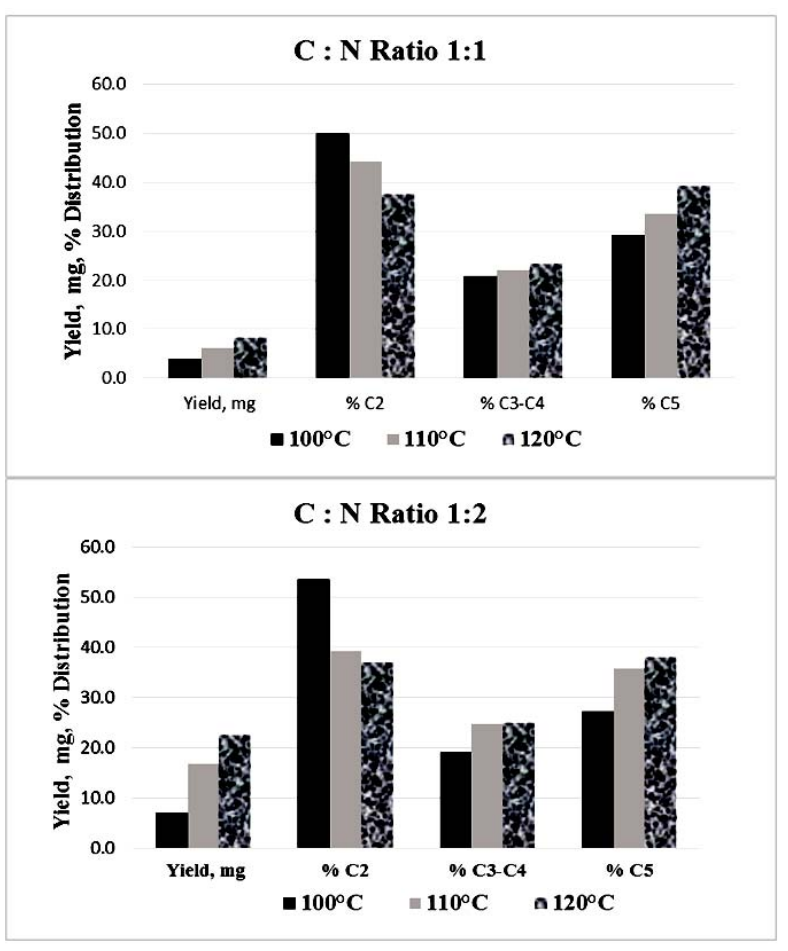

Figure 6. Effect of temperature and $\mathrm{C}: \mathrm{N}$ mole ratio on synthesis of pyrazines using acetol and $\mathrm{NH}_{4} \mathrm{OH}$.

of "tar" at the bottom of $40 \mathrm{~mL}$-reaction vessel was found to be very low. For this reason, a small volume of methanol $(1 \mathrm{~mL})$ was sufficient to dissolve everything and include it with the remaining reaction material.

After the completion of the reaction, portions of the aqueous solution were distilled $(3 \times 375 \mathrm{~mL})$ at an oil bath
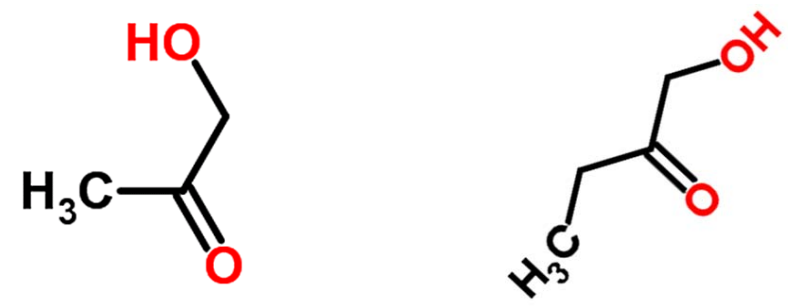

Figure 7. The structure of acetol or 1-hydroxyacetone (left) and 1-hydroxy-2-butanone (right).

temperature of $130-140{ }^{\circ} \mathrm{C}$ (16). In each distillation (375 mL), approximately $175 \mathrm{~mL}$ of aqueous solution containing different pyrazines was collected (light yellow color, total volume collected amounted to about $500 \mathrm{~mL}$ ). The distilled materials $(3 \times 175 \mathrm{~mL})$ were combined and passed through a $\mathrm{C} 18$ column $(15 \times 2.5 \mathrm{~cm}$ packed with SPE material) in order to remove the pyrazines from the water. After removal of the water from the C18 column using a gentle stream of dry nitrogen, the trapped pyrazines were eluted using ethanol. Ethanol was removed using a rotary evaporation and vacuum. Residual water in the final product was removed from the pyrazines by dissolving them in MTBE and drying over anhydrous sodium sulfate. MTBE was then removed using a rotary evaporator and vacuum. Three pyrazines were detected in a DCM extract of the reaction mixture after distillation. These pyrazines thus remained behind in the reaction mixture and were not distilled, possibly due to their non-volatility with steam and their higher molecular weight. The failure of these pyrazines to be distilled contributed to a lower percent

Table 6. Mass and distribution of isolated pyrazines after distillation and isolation from a relatively large scale reaction of acetol and $\mathrm{NH}_{4} \mathrm{OH}$.

\begin{tabular}{|c|c|c|}
\hline Peak \# & Pyrazine & Yield (mg) \\
\hline 1 & ISTD $^{a}$ & 0.25 \\
\hline 2 & 2,6-dimethylpyrazine & $290.1(9.9)^{b}$ \\
\hline 3 & 2,5-dimethylpyrazine & $838.9(28.6)$ \\
\hline 4 & 2-ethyl-5-methylpyrazine & $45.3(1.5)$ \\
\hline 5 & 2-ethyl-6-methylpyrazine & $20.3(0.7)$ \\
\hline 6 & 2,3,5-trimethylpyrazine & $297.1(10.1)$ \\
\hline 7 & ethyldimethylpyrazine isomer & $198.3(6.8)$ \\
\hline 8 & ethyldimethylpyrazine isomer & $208.4(7.1)$ \\
\hline 9 & 2,3,5,6-tetramethylpyrazine & $25.9(0.9)$ \\
\hline 10 & 2,3,5-trimethyl-6-ethylpyrazine & $54.7(1.9)$ \\
\hline 11 & 2,6-dimethyl-3-propylpyrazine & $41.9(1.4)$ \\
\hline 12 & 2,5-diethyl-3,6-dimethylpyrazine & $26.9(0.9)$ \\
\hline 16 & 2,5-dimethyl-3-propylpyrazine & $45.6(1.6)$ \\
\hline 17 & dimethyl-3-cis-propenylpyrazine isomer & $151.9(5.2)$ \\
\hline 18 & dimethyl-3-cis-propenylpyrazine isomer & $27.1(0.9)$ \\
\hline 19 & 2-isopropenyl-3,6-dimethylpyrazine & $656.0(22.4)$ \\
\hline \multirow[t]{2}{*}{20} & 2-(2-methylpropyl)-3,5-dimethylpyrazine & $4.7(0.2)$ \\
\hline & Total mass of pyrazines $(\mathrm{mg})$ & 2932.9 \\
\hline
\end{tabular}

\footnotetext{
a ISTD: Internal standard

${ }^{b}$ The number in the brackets represents the (\%) distribution
} 
yield. These "non-steam-volatile" pyrazines were identified as 2-(2-methylpropyl)-3,5-dimethylpyrazine (12.57 $\mathrm{min}$ ), 2,6-dimethyl-3-isobutylpyrazine (12.74 $\mathrm{min})$, and 2-(2-methylpropyl)-3,5,6-trimethylpyrazine (12.95 $\mathrm{min})$. The presence of those pyrazines in the reaction mixture confirms the participation of the free amino acids from the hydrolyzed $\mathrm{F} 1$ protein in the pyrazine synthesis. Table 6 shows the quantity of each individual pyrazine and its percent distribution after distillation, isolation, and extraction with MTBE. Of note is the observation that four pyrazines: 2,6-dimethylpyrazine; 2,5-dimethylpyrazine; 2,3,5-trimethylpyrazine; and 2-isopropenyl-3,6-dimethylpyrazine accounted for $71 \%$ of the pyrazine distribution, in the final product. A group of dimethylpyrazine derivatives, ethyldimethylpyrazine isomers and dimethylisopropenylpyrazine isomers accounted for an additional $20 \%$ of the total. The yield of total pyrazines from distillation of $1200 \mathrm{~mL}$ of reaction solution ( $100 \mathrm{~g}$ of 1 -hydroxyacetone $+100 \mathrm{~mL}$ of $\mathrm{NH}_{4} \mathrm{OH}$ ) was about $60 \%$ of the value that would have been projected from the yield obtained from the $12 \mathrm{~mL}$ reaction $(1 \mathrm{~g}$ of 1-hydroxyacetone $+1 \mathrm{~mL}$ of $\mathrm{NH}_{4} \mathrm{OH}$ ). This yield calculation does not include contribution from the pyrazines that remained in the post distillation reaction mixture. The lower \% yield could be due to a variety of causes among them being loss of sample during the clean-up process and differences in isolation/extraction efficiencies. Also, the lower percentage could be due to formation of the "tar"-like material at the bottom of the large reaction vessel which was only soluble in methanol.

\section{CONCLUSIONS}

Optimized reactions of alpha-hydroxyketones with different nitrogen bases, aldehydes, and free amino acids as secondary nitrogen sources have been shown to produce a wide array of pyrazines. Changes in $\mathrm{pH}$, reaction temperature and reaction time had nominal but consistent impacts on the pyrazine distribution, both qualitatively and quantitatively. The results showed that using optimized conditions $(\mathrm{C}: \mathrm{N}$ mole ratio $=1: 2$, temperature $=120^{\circ} \mathrm{C}$, reaction time $=16 \mathrm{~h}$, and $\mathrm{pH}=11-12$ ) at least 19-20 different pyrazines could be readily synthesized and isolated using a combination of atmospheric distillation and column chromatography. Addition of amino acids or a selected aldehyde altered the qualitative distribution of synthesized pyrazines, and also the pyrazine yield. Results further confirmed the hypothesis that steering the structure(s) of the alpha hydroxyketone carbon source(s) coupled with the presence or absence of free amino acids and aldehydes can offer unprecedented control of the types of pyrazines being synthesized.

\section{REFERENCES}

1. Shibamoto, T. and R.A. Bernhard: Investigation of Pyrazine Formation Pathways in Sugar-Ammonia Model System; J. Agric. Food Chem. 25 (1977) 609-614. DOI: $10.1021 / \mathrm{jf60211a055}$

2. Shibamoto, T. and R.A. Bernhard: Effect of Time, Temperature, and Reactant Ratio on Pyrazine Formation in Model System; J. Agric. Food Chem. 24 (1976) 847-852. DOI: 10.1021/jf60206a045

3. Coleman III, W.M. and T.J. Steichen: Sugar and Selected Amino Acids Influence on the Structure of Pyrazines in Microwave Heat-Treated Formulations; J. Sci. Food Agric. 86 (2006) 380-291. DOI: 10.1002/jsfa.2363

4. Coleman III, W.M.: On the Synthesis and Characteristics of Aqueous Formulations Rich in Pyrazines; in Flavor, Fragrance, and Odor Analysis, edited by R. Marsili, CRC Press, Boca Raton, FL, USA, 2012 pp. 135-181.

5. Newell, J.A., M. E. Mason, and R.S. Matlok: Precursors of Typical and Atypical Roasted Peanut Flavor; J. Agric. Food Chem. 15 (1967) 767-772.

DOI: $10.1021 / \mathrm{jf} 60153 \mathrm{a} 010$

6. Ara, K.M., L.T. Taylor, M. Ashraf-Khorassani, and W.M. Coleman III: Alkyl Pyrazine Synthesis via an Open Heated Bath with Variable Sugars, Ammonia, and Amino Acids; J. Sci. Food Agric. 97 (2017) 2263-2276. DOI: $10.1002 /$ jsfa.8039

7. Ara, K.M., L.T. Taylor, and W.M. Coleman III: Conversion of Tobacco Biomass to Flavor Components by Means of Microwave and Parr Reactors; Beitr. Tabakforsch. Int. 27 (2017) 102-112.

DOI: $10.1515 / \mathrm{cttr}-2017-0011$

8. Fors, S.M. and B.K. Olofsson: Alkylpyrazines, Volatiles from the Maillard Reaction: II. Sensory Properties of Five Alkylpyrazines; Chem. Senses 11 (1986) 65-77. DOI: $10.1093 /$ chemse/11.1.65

9. Fors, S.M.: Sensory Properties of Volatile Maillard Reaction Products and Related Compounds; in The Maillard Reaction in Foods and Nutrition, edited by G.R. Waller and M.S. Feather, ACS Symposium Series, Washington, DC, USA, Volume 215, pp. 185-286. DOI: 10.1021/bk-1983-0215.ch012

10. Coleman III, W.M. and S.N. Lawson: An Automated Solid-Phase Microextraction-Gas ChromatographyMass Selective Detection Approach for the Determination of Sugar-Amino Acid Reaction Mechanisms; J. Chromatogr. Sci. 37 (1999) 383-387.

11. Pawliszyn, J. and W.M. Coleman III: SPME-GC-MS Detection Analysis of Maillard Reaction Products; in Application of Solid Phase Microextraction, edited by J. Pawliszyn, RSC Chromatography Monographs, The Royal Society of Chemistry, Cambridge, UK, 1999 , Chapter 43, pp. 585-608.

DOI: $10.1039 / 9781847550149-00585$

12. Coleman III, W.M.: Method of Providing Flavorful and Aromatic Compounds in Absence of Reducing Sugars; US Patent 6,325,860 B1, December 4, 2001; available at: https://patentimages.storage.googleapis.com/7e/5c/31/ 768337d5b7e79d/US6325860.pdf(accessed July 2019).

13. Coleman III, W.M.: Synthesis of Materials Rich in Pyrazines Employing no Sugar; J. Sci. Food Agric. 80 (2000) 1262-1270. DOI: 10.1002/1097-0010 (200006)80:8\%3C1262::AID-JSFA634\%3E3.0.CO;2-T

14. Ashraf-Khorassani, M., W.M. Coleman III, M.F. Dube, and L.T. Taylor: Isolation of Free Amino Acids via Enzymatic Hydrolysis of Tobacco-Derived F1 Protein; Beitr. Tabakforsch. Int. 28 (2018) 103-111.

DOI: $10.2478 / \mathrm{cttr}-2018-0011$

15. Ashraf-Khorassani, M., W.M. Coleman III, M.F. Dube, and L.T. Taylor: Isolation and Purification of Pyrazines Produced by Reaction of Cellulosic-Derived Sugars with $\mathrm{NH}_{4} \mathrm{OH}$ and Selected Amino Acids; Submitted J. Chromatogr. Sci. for Publication, 2019. 
16. Coleman III, W.M. and A.R. Gerardi: Method of Preparing Flavorful and Aromatic Compounds; US Patent Application 2010037903 A1, February 18, 2010, available at: https://patents.justia.com/patent/ 20100037903 (accessed July 2019).
Corresponding author:

Mehdi Ashraf-Khorassani

Department of Chemistry, Virginia Tech

Blacksburg, VA 24061-0212, USA

E-mail:mashraf@vt.edu 